\title{
2. Professor Tim Congdon CBE
}

PA: Good morning, Professor Congdon. Which field of economics do you consider to be your specialism?

TC: I'm a monetary economist. So I'm interested in the role of money and banking in the determination of macroeconomic outcomes.

PA: And within that specialism what would you consider to be the main issue related to your field?

TC: At the moment, the problem I face is that that the core macroeconomic theory taught in most universities - and, indeed, understood in most central banks - doesn't really integrate the banking system and the quantity of money into the determination of macroeconomic outcomes. Whereas I regard what happens in the banking system, what happens to the quantity of money, as absolutely fundamental.

PA: Could you summarise the underlying axioms, the basic principles, of your beliefs?

TC: Two ideas are central. The first one is that the demand to hold real money balances depends only on real things in the long run. Having said that, second, in the short run, all sorts of strange things happen - and so I would say, developing these themes, that in the long run movements in the price level are determined by changes in the quantity of money relative to changes in the quantity of goods and services, and inflation occurs only through excessive monetary growth. But in the short run, large fluctuations in real money balances cause macroeconomic instability, meaning above or beneath trend growth in demand or output, boom or bust, overheating or recession, and so on. These ideas are central, but they are not new and have often been expressed in the past by supporters of the quantity theory of money. Perhaps the crucial new and distinctive element in my work is the emphasis on an all-inclusive (or 'broadly-defined') measure of money as the one to which the key quantity-theory propositions relate. It follows that large fluctuations in the growth rate of real broad money matter - and sometimes matter enormously - to asset prices and economic activity. This proposition - which has a very monetarist flavour - has been vital to the forecasts, and economic and investment advice, I have given over 
the years. ${ }^{1}$ Nowhere does it appear in the fashionable macroeconomic theories of today.

PA: In your work, generally, would you say that history has a role to play? And if so, what sort of role would it have?

TC: History has a massive role to play, in two ways. One is that history provides the evidence on which an economist's critical assertions can be established or not. Critical assertions may be theoretical in some sense, and theoretical and abstract if you wish, but they must be tested against evidence which comes from history. And the second is that the history of thought provides examples of the best thought, of the best thinkers in the past, from which we benefit.

PA: In terms of mathematics, would you say maths is useful to you? And if it is, how do you use the maths? How would it be beneficial to your work?

TC: I'm not a mathematical economist. Again two answers here. One is I do believe in confronting ideas against evidence, and then obviously there are all the standard issues with econometric testing. The second point is that mathematical economics isn't really about econometrics, it's a separate subject. It's about the representation in symbols of economic categories and the algebraic manipulation of these symbols by mathematics to obtain results. I have no objection to the use of mathematics in economics as long as it's kept in proportion. I'm deeply opposed to the idea that ideas are good because they're complex and require difficult mathematical exposition to establish their veracity or to be of professional interest, indeed to establish the credentials of the academic concerned. Complexity and remoteness from the real world - these are failures, they are not good things, not things to encourage in academic work.

PA: Thank you. And if you were looking more specifically, are you familiar with the credit and state theories of money - maybe Innes, Knapp - and if you are familiar, do you think they have any value?

TC: Of course I know of Knapp and his idea that the value of money depends upon the legal framework and legal tender laws. This seems to me obviously true in modern circumstances. I looked at Knapp's book, The State Theory of Money, many years ago, partly because of its relevance to a paper I was then writing, on the evolution of money, banking and central banking. ${ }^{2}$ There was an evident tension - even as early as the late nineteenth century - between the German Historical School (to which Knapp belonged) and the Austrian free market school. My natural inclination, as a supporter of free markets, was and still is to be on the side of the Austrians. In my view the evolution of money 
is best understood from an Austrian perspective, with a variety of search processes. Many of the processes - to recall a phrase that Hayek borrowed from the eighteenth-century Scotsman, Adam Ferguson - can be viewed as leading to 'results of human action, but not the execution of any human design'.

PA: So you would agree with the seminal paper by Menger in 1892 ?

TC: Indeed. The Menger 1892 paper in the $E J-$ Menger against Knapp, if you wish - brought out the contrast between the two ways of thinking. ${ }^{3}$ I'm also aware of, in more recent decades, the work of people like Randall Wray, the Post-Keynesian circuitists and horizontalists, and so on, with Wray's 2012 Modern Money Theory being perhaps the focal work. ${ }^{4}$ I'm much more sceptical about them. They correctly point out that banking institutions - such as the legal tender status of central bank money and the endogeneity of much money creation in modern economies - have certain implications for monetary economics. I have no difficulty with that. But in my view they leap to conclusions which aren't justified. I'm very much of the view that, despite the endogeneity of much money creation, the processes of money creation are separate from the processes by which agents adjust to money balances. The monetary forces that affect spending behaviour and portfolio decisions are an independent influence on the determination of macro outcomes. The direction isn't entirely from macro outcomes to the determination of the quantity of money, as the Post-Keynesian horizontalists would have us believe. Rather it is mostly from the quantity of money to macro outcomes.

PA: That pre-empts my next question: would you consider the quantity of money exogenous, endogenous or an element of both?

TC: I'd say there are two different concepts of endogeneity and exogeneity. One is model endogeneity and exogeneity, and that is where you have a model for thinking about the economy with a mixture of dependent and independent variables, and where you regard some as independent causative variables, which are the exogenous variables, and the dependent as endogenous. This is not quite the same thing as the second meaning, which is policy endogeneity and exogeneity. In policy exogeneity the variable under consideration, which may be the quantity of money, is deemed to be under the control of the policy-makers and hence exogenous, or not.

When it comes to money, I have set out an eight-quadrant diagrammatic model which describes the banking system in a modern economy. ${ }^{5}$ The quantity of money is determined, as are other monetary variables, in Marshallian fashion by supply and demand diagrams. In the relevant quadrant the quantity of money is equal to the quantity of bank credit, minus the banking system's capital. So, with the equity capital taken as given, changes in the quantity of 
money are equal to changes in bank credit, where bank credit means bank lending to the private sector. In this account - which is bang in line with Post-Keynesian horizontalism - money is determined endogenously, in the sense that it reflects decisions by private sector agents rather than decisions by the central bank or the government. ${ }^{6}$ I do regard that approach as being correct much of the time.

Having said that, the central bank and government can alter the quantity of money directly through what I call 'debt market operations' in one of my essays. ${ }^{7}$ These debt market operations were exemplified in so-called 'Quantitative Easing' for some years after 2008. Even when those kinds of operations are not being deployed, the central bank can affect the rate of growth of bank credit for the private sector, and hence of the quantity of money, by changing interest rates.

I've given a somewhat complex answer. It may well be that processes of money creation are endogenous in the model endogeneity sense of that word. I accept that. But that does not mean policy-makers can ignore money. The state can still strongly influence the rate of growth of the quantity of money. Further, over periods of, for example, five or ten years, that strong influence in one direction or the other effectively means control.

PA: Thank you. How would you view banks when building theories or models - do you take them to be pure intermediaries between savers and borrowers, or credit creators?

TC: There is no doubt at all that banks can create new credit, and new money, out of thin air. Quite an important part of my current MSc lecture course [at the University of Buckingham] is to discuss the process of money creation in a credit-money economy which has this characteristic. ${ }^{8}$ Key to it is that the banks must make their money accepted in transactions, as Hyman Minsky, for example, emphasised correctly. The process of money creation out of thin air by commercial banks is nevertheless subject to limits. It is constrained by the requirements both that banks maintain capital against the risks in balance sheet extension, and that they have cash to meet deposit withdrawals and to honour their obligations in inter-bank settlement. So commercial banks' ability to create money, bank deposits, out of thin air is constrained. The same constraints do not apply to the central bank. The central bank can create money without limit, in almost infinite quantities, from thin air. We know what happens in those circumstances, that is, when it does let its balance sheet and monetary liabilities explode very rapidly. We risk hyperinflation. So in most civilised, advanced societies, there are constitutional constraints on what the central bank can do. Although legal tender money can theoretically be created out of thin air without limit, in practice that is not allowed in most countries. 
PA: In terms of interest rates, if you were doing a theoretical diagram to show how they were determined, what would it look like? And if you were making some amendments and concessions to the real world would it look the same? Would you distinguish between theory and practice?

TC: I have written a brilliant paper that sorts out this subject completely! ${ }^{9}$ The heart of it is the eight-quadrant diagrammatic description of the banking system just mentioned. To elaborate, the banking system has two parts, the central bank and the commercial banking system. The correct approach to understanding how it works is to remember that both these parts have two sides to the balance sheet, assets and liabilities, and that our supply and demand diagrams determine both a price (that is, an interest rate) and a quantity. So we determine four monetary interest rates and four monetary quantities.

In my view, the best way of understanding what happens on the asset sides of both the central bank and the commercial banking system balance sheets is Post-Keynesian horizontalism. ${ }^{10}$ It seems to me reasonable to regard the supply functions of both central bank credit and commercial bank credit as horizontal to the $x$ axis, in normal conditions for most of the time. There are various caveats to that idea, but it is the correct way to think about the subject.

However, when we think about the liabilities side of the balance sheet, in my view it's much more productive to think in verticalist terms. We get back to the textbooks and recover Keynes's liquidity preference theory of 'the rate of interest'. Obviously, this raises questions about the characteristics of different types of bank customer, and that's for discussion. The whole subject is very institutional.

As I said, my 'apparatus of thought' - my eight-quadrant diagram - determines four interest rates and four quantities. In the two quadrants that relate to the central bank's assets, the central bank discount rate equilibrates the supply of central bank credit with the banking system's demand for such credit; in the two quadrants that relate to the central bank's liabilities, the inter-bank rate equilibrates the banking system's demand to hold monetary base with the quantity of base actually in existence and arising from the central bank's past operations; in the two quadrants that relate to commercial banks' assets, their lending rate equilibrates their customers' demand for bank credit with the commercial banks' credit supply; and in the two quadrants that relate to commercial banks' monetary liabilities (that is, their deposits), the bond yield equilibrates the demand to hold deposit money with the quantity of deposit money created by the banking system. Plainly, the determination of the bond yield in the final two quadrants is fully consistent with Keynes's liquidity preference theory. A horizontal supply function of bank credit is therefore compatible with the standard Keynesian story. 
Let me add that, if realistically we allow bank capital to influence the position of the supply function of commercial bank credit, we can also analyse credit spreads, the margins that banks charge over the inter-bank rate, their marginal cost of funds. This is all within a single analytical framework, in which different parts of banking system are related. As far as I'm concerned, I've sorted this subject out. Whether I've persuaded other people about the matter, we'll have to see.

PA: On a related point, to what extent do you think the central bank has the capability to control the whole spectrum of interest rates? And if you think it can, to what extent do you think it should?

TC: The problem with the answer I've just given you is that it's very focused on money-related interests. As far as I'm concerned, there is no doubt the central bank can control its own discount rate, its own lending rate, because it is the monopoly supplier of base money. The claims made by many people, often from a free-market background, that the central bank cannot control real interest rates ... Well, the central bank certainly can and does control short-term nominal rates. In my framework, this power arises - very simply - from the application of standard supply and demand analysis, and from the indisputable fact that the central bank is a monopolist.

Now I accept that a larger issue is whether the central bank can control real rates in the long run without causing global instability. By 'global instability' I mean a descent into hyper-depression, because of a self-reinforcing contraction of the quantity of money, or an ascent into hyperinflation, because of a limitless explosion in the quantity of money. This is a much more difficult question. Clearly, in any economy there must be an equilibrium relationship, or relationships, between the money rates of interest (the central bank rate, the inter-bank rate and so on) and real rates of interest. That must be so. But in the long run real interest rates are determined by real forces, including time preferences and the marginal productivity of capital. I go completely along with the classical school there. Obviously, the problem for the economy is to reach an equilibrium which matches up what's going on in the banking and financial system on one side with the development of the real forces on the other.

Suppose, for example, that a central bank is determined to keep on driving down the long rate of interest and it is utterly indifferent to the impacts on the quantity of base money and the quantity of money, which explode rapidly. Then you'd get a hyperinflation. So you might analyse the supply and demand diagrams and the four parts of my model, and derive the money rates of interest, and the various credit and money quantities. You can certainly put together stories in which the current Venezuelan situation or the 1923 Weimar situation emerge, or at the opposite extreme you can put together a story of the plight of 
the US banking system in February-March 1933. These quite different examples of severe instability can be seen as emerging from the central bank setting the wrong nominal rate of interest.

PA: If you heard the term heterodox economics, what would you think it meant? And if there were any specific groups of economists you would consider to be heterodox, what would those be?

TC: 'Heterodox economics' is usually applied to Post-Keynesians and particularly to rather left-wing Post-Keynesians. But Post-Keynesian economists are far from unanimous and there have been important debates. Simplifying, there was a well-known division between the accommodationists (who wanted to ditch Keynes's liquidity preference theory of 'the rate of interest') and the structuralists (who didn't). ${ }^{11}$ The split was notably between Victoria Chick and Sheila Dow on the structuralist side, and then a whole range of people (for example, Basil Moore and Marc Lavoie) on the Kaldorian accommodationist side. I would take the phrase 'heterodox economists' to include a diverse range of people. What they have in common is a rather cynical and sceptical view of capitalist financial institutions and the antics of the banking system, plus a strong interest in how finance works, and also a belief in Marxism and a support for public ownership.

PA: So - and it's quite controversial - would you think that Austrian economists are not a heterodox school? Or would they be heterodox, but totally different to the groups you just mentioned?

TC: I wouldn't think of the Austrians as heterodox. Their politics are utterly different from the Post-Keynesians. Basically, they support the market economy, and believe in the value of search processes and market incentives to find equilibrium prices. However, some Austrians dislike the notion of equilibrium prices altogether - that does put them in touch with many of the Post-Keynesians. In general, the Austrians are interested in and applaud the incentives and motives that characterise the capitalist economy. So they are very different from the left-wing people I'd regard as heterodox.

PA: That's interesting. This is a kind of 'Keynesian beauty contest' sort of question: from what you perceive the average opinion within the field of economics and the people you work with (and you can define that in any way you wish) what would their view be of heterodox economics?

TC: A live question in the social sciences is the value of interdisciplinary work. We can have a history of anthropology and an anthropology of historians. There are anthropology, sociology, history ... and there is economics. And some economists regard economics as the monarch, the 'queen' of the 
social sciences, because of its rigour, its formalisation, its ability to generate propositions that can be tested, and so on. Well, maybe.

Those economists - say, the New Classical School - who emphasize the uniqueness of economics, and its rigour and formalization, tend to scorn the Post-Keynesians because the Post-Keynesians are supposedly more verbal and woolly, and less rigorous and technical, than they are. Let me say here that I disagree strongly with much of what comes out from the Marxists and the left-wing strand in post-Keynesianism. But some of the left-wing strand is interesting. Suppose we're talking about the corporate economy. Then we're assuming individuals, with their different mind-sets and motives ... and also companies. But actually there's an inescapable prior assumption that companies exist. Now does that assumption make sense unless there is also private property? And, if you're a historian and you're interested in the evolution of everything, including the corporate form and the institution of private property, you ask 'how did this all get going?' You may be an economist, but you cannot escape history and the social sciences other than economics. Sometimes these are important questions to ask. I regard the contributions of the heterodox school as very provocative and interesting. Although I disagree with much of what I have learned from reading heterodox and Post-Keynesian economists, still I have learned an awful lot.

PA: This is, perhaps, an unusual question to ask - but to what extent would you call yourself a heterodox, inasmuch as you're a critic of the New Consensus Macroeconomics? Would you class yourself as heterodox? It's obvious you're not a Marxist, you're a free-market advocate - but are you heterodox in that you're not orthodox?

TC: The problem with economics today is that there is no orthodoxy! I have written a magazine article in which I suggest that microeconomics and welfare economics are relatively well mapped-out and understood. ${ }^{12}$ I accept that you can debate and discuss that, but the case can be made. Meanwhile macroeconomics is a complete mess. It's a shame that it's a complete mess and perhaps it shouldn't be, but there we are. In my view, much of the trouble reflects the contemporary neglect of money and banking in macroeconomic analysis. I concede that I am an outlier in today's economics. But this arises from my emphasis on the importance of money and banking to macroeconomic outcomes, while the profession nowadays de-emphasizes it. All the same, I regard my approach as very much in the mainstream of traditional monetary economics, and not in the slightest heterodox. My isolation is due to what I regard as the mess in the subject, this notion that you can engage in macroeconomic analysis without mentioning the quantity of money. 
PA: Following from that, the core question concerns this New Consensus Macroeconomics, and what I mean by that is New Classicism, New Keynesianism (probably predominantly New Keynesianism) - would you say that the events of the global financial crisis provide contradictory evidence to this consensus, this New Keynesianism, centred in the American New Keynesian school? And if you do think so, what sort of evidence would you think it was?

TC: I'm not sure the phrase 'contradictory evidence' really gets to it. The real problem with New Keynesian economics is that the categories it contains are so limited that it cannot provide useful and realistic interpretations of the modern world. It's as bad as that!

The extreme illustration comes from the three-equation New Keynesianism advanced in the 1999 Journal of Economic Literature article by Clarida, Gali and Gertler. ${ }^{13}$ To recall, the three equations are: the one that allegedly lies behind the 'IS curve', with aggregate demand a function of 'the rate of interest', the expectations-augmented Phillips curve, usually expressed not with unemployment, but with 'the output gap', which is seen as a determinant of the change in inflation, and the Taylor rule, which is a 'central bank reaction function' showing how the central bank changes the rate of interest in response to values of inflation and the output gap.

(Let me say here quickly, in a very critical spirit, that 'the rate of interest' in the three-equation New Keynesian model is the central bank rate. This is not 'the rate of interest' in the IS curve in the IS-LM model and Keynes's General Theory, which is the yield on the long bond.)

Now the assumption in the original formulation of all this was that economies would behave in such a way that a positive central bank interest rate would always be required. But during and after the Great Recession, in 2009 and 2010, the output gap was so negative and inflation so weak that mechanical applications of the Taylor rule indicated a need for significantly negative central bank rates. These were impossible. Why had matters become so out of hand? Why had the Taylor rule broken down?

My interpretation of the Great Recession is controversial, but in my view officialdom was largely to blame for the slump in demand. ${ }^{14}$ From October 2008 international regulatory officialdom - the International Monetary Fund and the Bank for International Settlements, in cahoots with national authorities - imposed a sharp increase in banks' capital-to-asset ratios. It was this step that converted a relatively manageable downturn into the Great Recession. The jump in capital ratios stopped the banks making new loans and indeed required them to reduce their risk assets. The reductions in risk assets led to contractions in the quantity of money, which was massively deflationary ... and this had to be offset by slashing interest rates to zero. The variables at play 
in these events - such as banks' capital ratios, the quantities of bank lending to the private sector and the quantity of money - were not and are not included in the three-equation model. Quite honestly, the New Keynesian approach, at any rate in its three-equation version, contains such a limited range of variables, such a restrictive set of categories, that it does not provide useful insights into the macroeconomic instabilities of the modern world.

PA: From your perception, do you think that what happened in the crisis did anything to negatively impact the hegemony of the MCM? Did it hold its ground, and what were the effects in the short and medium term?

TC: I said I'm an outlier in contemporary macro; I'm really just not interested in New Consensus Macro, full stop. I have a model of the economy that works. I've used it on many occasions, helping clients with investment decisions, advising the British government, writing newspaper articles and books, and in millions of words of economic commentary. My approach works in understanding and commenting on the economy. I'm not interested in this three-equation rubbish. Frankly, I don't read the papers that have got all this sort of stuff in it. Many of them are very pretentious. I am an outlier, but my work is far from being totally ignored. I think it has had some influence. For example, at the Bank of England Ryland Thomas has written papers which pick up my approach. ${ }^{15}$ In my work the core question much of the time is 'if the rate of growth of the quantity of money changes, what happens all around the economy?' This is very much in a tradition of analysis which goes back centuries. It restores themes going all the way back to the Salamanca School, Cantillon and David Hume. We don't really know yet how long New Consensus Macro will be around. My guess is twenty years from now it will be moribund or dead.

PA: And do you think heterodoxy will have a chance of replacing it?

TC: My position is absolutely straightforward. It's the kind of economics I do, that's my passion. First of all, you try to understand the forces that determine the quantity of money, on the broad definitions. You then analyse the demand to hold money balances by sector, the household sector, the company sector and so on. This sort of work enables you to identify monetary disequilibrium. Thus, rapid growth of money typically shows up in amplified form in the money balances of companies and financial institutions, and the disequilibrium - the excess money holdings - then affects expenditure and portfolio decisions. I think one of the difficulties in trying to place me - I am categorized as 'monetarist', but I'm certainly not in the New Classical School associated nowadays with Chicago - is that I have no embarrassment talking about disequilibrium. Nevertheless, I regard myself as being in what used to 
be a mainstream tradition, which says that national income and wealth are in equilibrium only when the demand to hold money is equal to the quantity of money created by the banking system. This proposition is in Keynes's General Theory. ${ }^{16}$ In fact, when Keynes said the proposition was fundamental, there wasn't any dispute about it with, say, Irving Fisher or Pigou. The proposition was also basic a few decades later in Patinkin and Friedman. But it has vanished from New Keynesianism, the New Classical School and so on.

I apologize - I haven't answered your question. But, no, I don't think heterodox ideas will drive policy-making a decade or two from now. My hope is that we see a return to traditional monetary economics.

PA: Straying into my own school now, which is Modern Monetary Theory or neo-chartalism; are you familiar with MMT's idea of operational reality, if you are, to what extent, if at all, do you consider it valid?

TC: Many of the assertions in MMT struck me as being certainly true when I had a look at the Wikipedia entry. (I haven't read Wray's Modern Money Theory with much care, to be blunt.) Indeed, many of them are true almost to the point of being banal. But other propositions struck me as being extremely contentious. Sure enough, a modern economy has legal tender money, issued by a central bank, and the central bank is set up by statute, and is answerable to the government of the day and also the legislature. The legal tender must be accepted in payment and in that sense the power to issue it is akin to the power of taxation. Further, the banking system takes payment instructions from non-banks to settle in this legal tender money ... and these arrangements which imply indeed that the value of money depends on law, and the state, are quite universal. I have no difficulty with any of this. I am not in favour of a return to commodity money, the gold standard and its ilk, and I am also totally opposed to such Austrian ideas as the denationalisation of money, the abolition of central banking and the end of legal tender laws, and the Chicago proposal for $100 \%$ cash reserve banking. I have no time for any of these particular Austrian and Chicago ideas.

PA: And would you consider that taxation funds government spending in an accounting sense? The MMT view is that the government can only collect money it's already spent - when the government or the state spend, it adds bank reserves to the system, when it taxes it takes reserves out. Warren Mosler would say that you can't have a reserve drain, which is what taxes are, until you've had spending. From your point of view, is it possible for the private sector to pay taxes unless the government's already spent the state money into existence? 
TC: Let me perhaps clarify this. It's plainly true that in a Soviet type economy, with public ownership, including public ownership of the banking system and of course all the means of production, the distinctions between the central bank and the state planning function, and the central bank and the commercial banking system, are not really meaningful. Essentially, the decisions on resource allocation are all subordinate to a state plan - and the banks, the central bank and so on, are simply channelling resources in line with these planning decisions. Indeed, it's quite important to notice that this is how communism works, or tries to. Now compare that to what we see in all the private enterprise, capitalist, free market economies of today, where you have a distinction between the usually state-owned central bank issuing legal tender money and the commercial banking system that is competitive and profit-maximising. The privately-owned banking system has the job of resource allocation and in principle the central bank doesn't do any of it. I'm not sure this really answers your question, but I have no difficulty with the notion that there is a central bank which is a creature of the state, that depends upon legal tender laws to get its money accepted.

PA: What I would say is, although MMT is associated with the left, it is in fact politically neutral. The argument of MMT is that when the government spends, it puts reserves in the banking system, and when it taxes, it takes them out. But the function of spending and taxation is to move resources from the private sector to the public sector. It's politically neutral, in that if you were someone that favours a small state and you believed that the private sector uses resources more efficiently, you would have a very low amount of spending and very low tax but allow the deficit to float in order to achieve full employment. If you were a left winger, you'd have a bigger state - more government spending, higher tax, but again the deficit would float. So, the distinctive aspect of MMT in that respect is that the public sector deficit is viewed as being the addition to private sector net saving. It's the sense that the government's deficit is exactly equal to the non-government sector's net saving in that year; any view of the deficit - the absolute figure, the percentage of it in terms of GDP - is meaningless, you just look at its real outcomes, for example, if you've got inflation which is due to excess demand, the deficit would be too big.

TC: Let's get this clear. If an economy is closed to the rest of the world - so that the external sector cannot have a financial deficit or surplus with it a government financial deficit must automatically, by identity, be matched by a private sector surplus. But that equivalence does not help us to understand the impact of the government's transactions on the quantity of money, and this impact is crucial. The government can finance its deficit by, for example, an identical issuance of long-term debt which is bought entirely by non-banks. 
In that case, there is no effect on the quantity of money and no effect on bank reserves. The effect on bank reserves applies only if the government finances the deficit by borrowing from the central bank. It isn't generally true. It is perfectly possible - because it has in fact happened in British experience - for the sales of long-term debt to exceed the budget deficit. ${ }^{17}$ The government can then use the excess proceeds from its sales of long-term debt to repay short-term debt held by the banking system. In other words, budget deficits can coincide with reductions in banks' cash reserves.

If you're trying to say that large budget deficits are harmless ... no, they're not, because the deficit has to be financed one way or another. If this deficit is financed in the short term, it is likely that sooner or later, on a sufficient scale, it will be inflationary; if it's financed long term, then the government has to pay a rate of interest on the debt, and the debt interest payments are themselves part of government spending. You get these dangers - of the sort seen in Greece of an explosion in debt, a breakdown in credibility, and basically a financial disaster. I myself can see no advantage in having large budget deficits at all.

Let me insert a qualification, although not usually an important one. To me the key condition for macroeconomic equilibrium, for steady growth with on-target inflation, is that the rate of growth of the banking system, bank deposits, be roughly equal to the desired rate of nominal GDP growth associated with the inflation target. This then implies that there must be corresponding growth in bank assets. It's possible that the private sector wants to repay its bank loans, meaning - if nothing else were being done - that there would be a contraction in the quantity of money. In these circumstances, the correct action by the state is to purchase something from the non-bank private sector to increase the quantity of money, and the best, cleanest, most ideal asset to purchase is its own long-term debt. It's what happened with QE in the UK. You might then develop a defence of public debts, and of the fiscal deficits that are a condition for the existence of such debts, but I think these ideas are somewhat remote from the staple fare of MMT theorists.

PA: It's interesting, your perception of it. On a simple level, how would you describe the balance sheet effects of government spending? If the government bought, say, a new submarine, what would actually happen in the banking system when the government spends the money?

TC: It depends on the financing of the deficit. Essentially the world consists of the government of a particular nation, and then the other agents in that nation (the central bank, the commercial banks and the non-bank private sector), and then of course there's the rest of the world. There are four types of government borrowing that can be done, corresponding to the four other types of agent. The macroeconomic effects are very different for each of those. If the effect 
of government borrowing is to increase the quantity of money by an addition to the monetary base times a multiplier, the deficit can be very inflationary. (I'm not saying I like monetary base thinking. I don't. Nevertheless, we have to be aware of the occasional legitimacy of a statement in these terms.) The deficit might be financed exactly from the commercial banking system, when the quantity of money rises by the extent of the deficit and there's no multiple. Alternatively, as discussed in my previous answer, the deficit might be financed by the sale of debt, at the long end, to private sector non-banks, in which case there's no effect of the quantity of money and no effect on equilibrium nominal GDP, but the ratio of public debt to GDP rises. And, finally, the deficit can be financed by borrowing abroad.

PA: What would you say the quintessential nature of QE is?

TC: Two kinds of QE can be distinguished. There was the kind of QE carried out in Japan between 2001 and 2004. Its essence was that the Bank of Japan bought assets from the banking system, which increased the bank's cash reserves, but didn't change the overall size of the banking system balance sheet or the level of deposits held by the private sector. At least the operations didn't increase bank deposits in the first instance. It was possible that, because the banks then had excess cash reserves, they might want in second and third rounds to expand their balance sheets by making new loans, and hence creating new deposits. But this wasn't how things really panned out in Japan, and there was relatively little effect from the 2001 to 2004 QE on the rate of growth or quantity of money. ${ }^{18}$ The same sort of comment applies to the Bank of Japan's more recent programme of so-called 'quantitative and qualitative easing', although QQE may latterly have had some small positive effect on the quantity of money.

And then there is what we did in the UK. Mervyn King made it quite clear in his interview on the BBC with Stephanie Flanders in early 2009 that the aim of QE in the UK was to increase the quantity of money, broadly defined. The emphasis on broad money was very 'Congdonite'! ${ }^{19}$ It was clearly intended that the purchases by the central bank, of government bonds, would be of bonds held at the long end and middle part of the maturity spectrum. They would not be exclusively from banks, but predominantly from non-banks. The Bank of England borrowed from the commercial banks in the first instance, by crediting cash to commercial banks' cash reserves for that purpose. The Bank then bought longs, which increased the bank deposits of the sellers of the bonds. The sellers were of course pension funds, insurance companies and others ...

There was a relatively direct and mechanical relationship between the size of the QE operations and the effect on broad money. Admittedly, there were 
some offsets. These were in fact discussed by Ryland Thomas in his chapter of the 2017 book I edited on Money in the Great Recession. ${ }^{20}$ I won't go into them all now, but I acknowledge it isn't necessarily the case that, if central bank purchases from non-banks are, say, £100 billion, the eventual impact on broad money is exactly $£ 100$ billion. All the same, the figure is unlikely to be dramatically less. So that was QE in the UK sense. It's pretty clear from what Mervyn King said, and also from the articles in the Bank of England's Quarterly Bulletin on QE, that that is what they were doing, which was bang in line with my own thinking. ${ }^{21}$

But this was and remains only one strand in the international discussion of QE. I think some people in the European Central Bank were influenced by the Bank of England approach, but this is for debate. The Federal Reserve is on a different planet! The Fed is in such an intellectual mess that it has people who think the purpose of $\mathrm{QE}$ was to reduce credit spreads. This is indeed what Bernanke himself said. The Fed's economists were not and still are not interested in the effect of its activities on the quantity of money.

PA: I don't know if you're familiar with the MMT's modelling - this idea of consolidating the Treasury and the central bank for operational purposes - do you think this is a valid structure as a starting point, would you agree entirely, or not at all?

TC: In some senses your suggestion is plainly true. It is clearly the case that - in the UK, for example, where we used to call them 'the authorities' - the Bank of England and the Treasury work together. The Bank and the Treasury ought to be jointly concerned with the effects of the consolidated state sector's actions on the private sector. I think this is particularly the case with what I call 'debt management operations', which are operations in government debt to affect directly the quantity of money held by non-banks. I have pointed out that these operations can be carried out either by the government or the central bank. ${ }^{22}$ In some circumstances it is better if they are done by the government, because - if so - there is no effect on the monetary base.

Suppose that a recession is threatened. The government can just go directly to the commercial banks and borrow from them by, say, the issue of Treasury Deposit Receipts, as in the Second World War. (Subsequently the TDRs became Treasury bills.) I have no difficulty with this. But notice the operational issues can evolve ultimately into constitutional issues. In the UK we have an independent Bank of England, responsible for monetary policy, and it would have to pay attention to large-scale government borrowing from commercial banks. Such borrowing would have major monetary effects which bypassed its balance sheet entirely. 
However, I am talking about an extreme case. Normally, monetary policy is concerned with the effect of changes in interest rates on the banking system's claims on the private sector. The growth of these claims ought to be sensitive to interest rates. In other words, the Bank of England's setting of interest rates affects the rate of growth of bank credit, which then affects the rate of growth of money. But we need to remember that, for much of the last decade, the situation was not normal. We had a situation in which the risk assets of the banking system - those claims on the private sector - were falling. Then, to keep banks' deposit liabilities growing at a steady rate, to keep money growth positive, the banks needed to have other assets. In practice, there has been - in the UK and elsewhere - a huge increase in the banking system's holdings of claims on the state. Now the process by which this was done had to be agreed in all countries by the government, by the finance ministry and by the central bank. In the UK we have this ridiculous institution called the Debt Management Office. It's not necessary to have an agency separate from the Treasury. Indeed, the fact that it exists tells you that in some sense the UK authorities are in a muddle.

PA: Just briefly - one of the core policies of MMT is the 'employer of last resort' policy? Do you have any comment on it?

TC: There are some people who think that the market economy is characterised by extreme instability. In their view the banking system is inherently mischievous and unstable, with its rate of growth all over the place, and as a result the market economy suffers from intrinsic instability. Keynes in The General Theory was one of these people. So he went on to say the government should be involved in smoothing the economy, with a 'somewhat comprehensive socialisation of investment'. His recommendation was that the government should change investment, public investment, to determine national income. He saw national income as a multiple of autonomous expenditure, meaning the sum of investment and government spending, and regarded changes in public investment as a stabiliser. And there are some Keynesians who might want to go beyond that and to have the government employ anyone who is unemployed, even just breaking stones. In your phrase the government would be the 'employer of last resort'.

No, I don't agree with that. The truth is that the market economy is characterised by very large numbers of job changes every year and the number of these job changes is much higher than the number of people unemployed. The labour market is extremely flexible, and employers and job-seekers need to be involved in and connected with the whole process of resource allocation. I don't believe the government is very good at allocating resources; I believe in choice, I believe in freedom, I believe in the private sector allocating resources. I therefore want, as far as is possible, a free financial system, meaning indeed 
a lightly regulated banking system. I think what's happened to the banking system since 2008 in terms of new regulation is a tragedy.

PA: In terms of your view of MMT, would you think it's a branch of Post-Keynesianism, or it's heterodox but separate? Or would you say it's difficult to tell?

TC: There is clearly a connection between the accommodationist school and the circuitists, and you have economists like Wynne Godley and Marc Lavoie who have been very interested in the flow of funds. In the case of Wynne Godley, you even had an economist who thought that flow-of-funds analysis, with stock-flow consistency, actually was monetary economics! ${ }^{23}$ I'm aware of these lines of thought, which sometimes segue into a MMT-style advocacy of active fiscal policy. To me flow-of-funds analysis is not monetary economics. Flow-of-funds analysis takes the view that the economy can be described by a number of identities, with no demand and supply functions in sight, and hence not much behaviour. Monetary economics on the other hand is, above all, about the achievement of monetary equilibrium, meaning equality between the demand to hold money and the quantity of money created by the banking system. In monetary economics we have to be concerned about the behaviour implicit in the relevant supply and demand functions. I wonder whether the flow-of-funds identities can by themselves provide the foundation for conceptualising a larger story of the economy. I'm sorry, but if you want to link up MMT with extreme Post-Keynesianism, of the accommodationist and circuitist sort, you have lost monetary economics as it was understood by Fisher, Keynes, Friedman, and so on. You have just lost it completely.

PA: From your community of economists - what would their view on MMT be? Would they have no opinion of it, maybe never really heard of it? Would they have an opinion of any sort?

TC: MMT is relatively new to me. I've been aware of Godley for many years, as we were both on the Treasury Panel of 'wise persons' in the 1990s. I have become aware of the circuitists, with their connections to flow-of-funds analysis and MMT, more recently. As I said earlier in this interview, much of MMT - the legal tender status of the central bank's liabilities and the ability to finance government spending from the banking system - isn't new. It does need to be stated, I have to say, but it's not particularly interesting or special. And then these leaps - into the advocacy of large-scale monetary financing of budget deficits - aren't justified. I think most economists would agree that the provocative bits are leaps that aren't justified by the facts.

PA: I am an MMT advocate, but I once spoke to an Italian economist who said that the general view of it was that 'what's new isn't interesting and what's 
interesting isn't new', and I thought that was quite an interesting summary of what many people think of it - although, of course, I don't agree with that view! It's a perception about it I've got from certain quarters, although people are generally generous and say that there are some things that, although they may seem obvious, they still need to be stated.

TC: The definitional points in MMT - that central banks are a creature of the state, and so on - are worth stating. I also absolutely agree that the state can finance its expenditure from the banking system, although the risks and dangers must be remembered. I think it's quite important to have these points of view stated.

PA: And in terms of methodology, what would your approach methodology be, in a very straightforward way? And do you think it's important to your work?

TC: I think we should describe and understand the economy correctly. I think we should then draw up theories, based upon those descriptions, which distinguish between analytical categories, different types of agent, companies, households, and so on, and various concepts of price and quantity. The theories should then help us to understand how the different categories relate to each other, and from there we should try to derive the best policy conclusions for the societies we live in.

So where does this place me methodologically? I don't really know. I'm more concerned really to find things that work than to ruminate and pontificate on methodology. Obviously, we have to question the extent to which theory and evidence are consistent, and also to question how far our macroeconomic theories are consistent with our macroeconomic judgements and analyses, both prognosis and prescription, in order to arrive at the right policy conclusion.

As far as I'm concerned, one should have tools that make sense in both a macroeconomic and microeconomic context. To illustrate, much of my work in monetary economics is about the demand-for-money functions of particular sectors of the economy, which might be seen as microeconomic. But I then have no difficulty also in talking about the aggregate quantity of money, which combines all the sector money holdings and is plainly macroeconomic. What you would find if you came on a lecture course of mine is that I have no difficulty appealing to categories found mostly in microeconomic theory and to others which help us to understand what's happening at a macroeconomic level.

PA: I'm going to try to limit myself to two more questions. Firstly, do you think pluralism is important, and you can interpret pluralism in any way you wish, there are a few ideas there, but mainly the idea that economics accepts 
different forms of pluralism, whether it be theories - or should it aim for one approach so that it increases its status? Should it be a discipline that encourages lots of perspectives?

TC: I'm very much a pluralist. I think that in understanding whether particular ideas work, one needs as much intellectual flexibility as possible. One needs to be open to heterodox ideas, as to other ideas. Also one shouldn't be in the least bit afraid to introduce ideas, analogies and concepts and so on, from all the other social sciences.

As an example, just this afternoon I had a discussion in a class about Kaldor and endogenous money. I asked the question, 'does the endogeneity of much money creation in a modern economy mean that national income determines the quantity of money rather than the other way around?' In my view the proposition that money endogeneity implies causation from national income to money is absurd. And my method to show it is absurd is to appeal to evidence, but curiously it is not direct statistical evidence on the link between money and national income that we want. Instead we need to check what bank assets actually are. Kaldor's claim - that national income determined money - turned on the availability of overdrafts, so that if - for any reason - someone had an excessive holding of money he or she would use the excess to repay part of the overdraft and the quantity of money would then have adjusted to the person's circumstances. So money adjusted to the economy, not the economy to money. But the force of this argument depends on the size of overdraft finance relative to the value of both loan transactions and total transactions. It is an easy matter to check from central bank data just how important - or rather how unimportant - overdrafts really are. The evidence is clear that they are a minor part of banks' business and utterly trivial relative to total transactions. We need a range of facts to understand the economy, some of which bear directly on key issues and some indirectly. We need to think very broadly, to be pluralist, if you wish.

Being blunt with you, I regard it as shocking how much influence Kaldor's views on endogenous money have had on thinking about money in British universities. Frankly, they're silly ideas. Friedman should have chopped them up forty, fifty years ago, as I'm trying to chop them up now. Bless Victoria Chick and Sheila Dow for seeing that, taken to extremes, Kaldor's views meant the end of the liquidity preference theory of the rate of interest and hence the destruction of Keynes's contribution to monetary economics. Chick and Dow were right to be prepared to stand up to Kaldor, Basil Moore and others.

PA: And the final question is, do you think a heterodox paradigm exists? Do the outliers, however you view outliers, have enough strength, do they have 
enough in common, to ever do anything against this New Keynesian hegemony? And do you think MMT has a role to play?

TC: I'm not sure there is a New Keynesian hegemony. I have a discussion - in the third lecture of my MSc course - on the different schools of thought found nowadays in monetary economics and macroeconomics. I mention Michael Woodford's Interest and Prices, which is very New Keynesian. I say in my lecture that in some circles Woodford's book is regarded as the Bible of modern central banking. Well, yes and no. You need to get a group of central bankers together to check. I would have thought that - if you did get together the chief economists and key policy-makers from central banks around the world - most of them would tell you that they don't find Interest and Prices very useful. Nowadays central banking is very much about output gap estimation and looking at survey evidence, and I'm afraid to a large extent it is atheoretical.

I believe there is a perfectly reliable theory, namely of course my theory! I mean the theory I use, with its focus on broad money and on the need for national income and wealth to be consistent with monetary equilibrium, where that equilibrium obtains when money demand and supply are equal. But I'm unusual in adhering to this theory, even though - as I said - I regard what I do as standard and traditional monetary economics.

PA: Well, that's the end of the interview. Many thanks, Professor Congdon. It's been a real pleasure.

\section{NOTES}

1. Congdon notes that, in particular, he used this idea successfully in the UK in the late 1980s. He based forecasts of a boom in demand and rising inflation on rapid growth of broad money in 1986 and 1987. The correctness of his forecasts led to his appointment to the Treasury Panel of Independent Forecasters (the so-called 'wise persons') in 1992. See Congdon (1992).

2. Congdon (1981).

3. Menger (1892).

4. Wray (2012).

5. Congdon (2018).

6. Congdon notes that Moore (1988) provides arguably the classic statement of Post-Keynesian horizontalism. It has five diagrams with $x$ axes in which 'loans' and 'deposits' appear as the same thing.

7. Congdon refers to his 'Essay 4' (Congdon 2011) which distinguishes between 'money market operations', where the central bank transacts with the commercial banking system to affect its behaviour, and 'debt market operations', where either the central bank or the government transacts directly with non-bank private sector agents, which can alter their money balances and lead to changes in spending and portfolios. 
8. Congdon notes that this is one way that a modern economy, with fiat money issued by the state at virtually nil resource cost, contrasts with a commodity-money economy, where the production of new money has a resource cost.

9. Congdon (2018).

10. However, Congdon cautions that Moore (1988) over-simplifies. In 'Revolution and Counter-Revolution in UK Banks' Asset Composition since 1945, and Why They Matter to the Debate on Horizontalism', a paper to be given at a festschrift event for Sheila Dow in autumn 2020, he argues that UK banks' asset composition has changed so radically over the decades that a precise and mechanical relationship between changes in loans and changes in deposits has not been observed in practice.

11. Congdon argues that numerous contributions have been made to the debate and that an attempt at resolution is offered by Chick and Dow (2013).

12. Congdon (December 2017-January 2018).

13. Clarida et al. (1999).

14. See Congdon (2017: chapters 1 and 2).

15. Ryland Thomas's work is often co-authored with Bank of England colleagues. See, for example, McLeay et al. (2014a, 2014b).

16. Keynes (1936: 84-5).

17. Congdon (1992) notes how the UK practice in the early 1980 s of selling long-term debt to non-banks in excess of the budget deficit was known as 'over-funding'.

18. In Essay 4, Congdon (2011: 67-71) describes the state of affairs in Japan - in which central bank operations increased banks' cash reserves, but did not cause banks to grow their balance sheets and deposit liabilities (i.e., money) - as a 'narrow liquidity trap'.

19. During the collapse in demand in late 2008 and early 2009 , Congdon emphasized the importance of official action to increase the quantity of money, broadly defined, by purchases of government securities from the non-bank private sector. See, for example, Congdon (2009).

20. Thomas (2017).

21. This was noted by the Bank of England's historian, David Kynaston (2017).

22. Congdon (2011: 76-7 and 417) discusses the different roles of the central bank and the government in the organisation of monetary policy in Essay 4. He points out in footnote 17 to the essay that the discussion arose in 2003 and 2004 from exchanges with Milton Friedman and Allan Meltzer, which predated the widespread adoption of QE from 2008.

23. See Godley and Lavoie (2012). 